\title{
The environmental consequences of ceasing dairy production
}

\section{Aaron Simmons ( $\square$ aaron.simmons@dpi.nsw.gov.au )}

New South Wales Department of Primary Industries https://orcid.org/0000-0002-3638-4945

\section{Zita Ritchie}

New South Wales Department of Primary Industries

\section{David Perovic}

New South Wales Department of Primary industries

\section{Guy Roth}

The University of Sydney

\section{Article}

\section{Keywords:}

Posted Date: February 4th, 2022

DOI: https://doi.org/10.21203/rs.3.rs-1247974/v1

License: (9) This work is licensed under a Creative Commons Attribution 4.0 International License. Read Full License 


\section{Abstract}

Climate change and water scarcity are major challenges facing the planet. Agriculture generates considerable GHG emissions and consumes water from rivers, streams and lakes. Reducing consumption of agricultural products with a relatively high carbon or water footprint, such as dairy, is often promoted as a mechanism to reduce the environmental impacts of food production. Using footprints to inform decisions is problematic because they represent the impacts of current production and not the consequences of re-allocating constrained resources such as land and water when demand for products change. We used consequential life cycle assessment to assess the water and climate change consequences of replacing NSW dairy production, and co-products of dairy production, with plant-based alternatives. Ceasing dairy production required the production of $125 \mathrm{kt}$ of soybeans for soymilk and tofu, $38 \mathrm{kt}$ of soymeal to replace meat meal and $8 \mathrm{kt}$ of vegetable oil as a cream alternative and also increased demand for agricultural land. We concluded that water savings associated with the change would be limited and emissions reductions would be $\sim 70 \%$ of that as estimated by the $C$ footprint of production. We also assessed the climate change consequences of replacing NSW dairy production with plant-based alternatives when two GHG emissions reduction strategies, enteric methane inhibitors and flaring methane from effluent ponds, were implemented across the industry. Results from this analysis suggested that replacing NSW dairy production if emissions reductions strategies are put in place will result in a net increase in $\mathrm{GHG}$ emissions of $0.57 \mathrm{Mt} \mathrm{CO}_{2}$-e. This work has important messages for setting climate change mitigation strategies including net-zero targets.

\section{Introduction}

Dairy products are consumed worldwide. They are a source of calcium and other nutrients with evidence suggesting that dairy consumption generally has positive health benefits ${ }^{1}$ and that dairy intake was associated with high quality diets ${ }^{2}$. Dairy is a key agricultural industry in New South Wales (NSW) where around $1 \mathrm{ML}$ of raw milk at the farm-gate are produced per annum, the sale of which contributes $\$ 647 \mathrm{~m}$ to the state's gross domestic product ${ }^{3}$. Dairy production is also a key user of natural resources such as water, with $\sim 170 \mathrm{ML}$ of water, or $5 \%$ of all water used for agriculture, in NSW used by the dairy industry ${ }^{4}$. Dairy production occurs in inland NSW, which is part of the Murray-Darling Basin, a catchment that is considered to be highly water-stressed ${ }^{5}$. Water is used in dairy production for purposes such as livestock drinking water, pasture irrigation and washing down dairies after milking. Dairy production also requires the use of land, both arable and non-arable. Arable land is used to grow pastures and crops that can be irrigated or un-irrigated depending on water availability. Non-arable land is generally used to graze heifers before they enter the milking herd and cows that are dried-off prior to calving. Dairy production also generates environmental impacts and one impact of key concern is the contribution of dairy production to climate change. Dairy production emits GHG gases primarily from enteric methane emitted by dairy cattle but also from other sources such as cattle manure, the breakdown of plant residues and the use of fertilisers and electricity usage ${ }^{6}$. 
The water and carbon footprints of dairy production have resulted in calls for reductions in dairy consumption to reduce the environmental impacts of consumer consumption $7,8,9,10$. However, environmental footprints are not suitable to be used to inform decisions ${ }^{11}, 12,13,14$ because footprints estimate the environmental impacts of current production, not the consequences of demand for one product being replaced with demand for a functionally-equivalent product. For example, research ${ }^{15}$ has demonstrated that replacing all agricultural production that occurs in England and Wales with organic production would increase the climate change impacts of food production, even though organic agricultural products have a lower carbon footprint.

Understanding the impacts of replacing dairy production would likewise mean assessing the impacts of producing functional equivalents of dairy. In addition to raw milk at the farm gate, dairy systems also coproduce animals (calves and cull cows) that enter the red meat supply chain, hence, an assessment of the consequences of a change in demand for dairy also needs to include the impacts of replacing coproducts of the system. For example, red meat is a co-product of a wool production system and research ${ }^{16}$ has demonstrated that the climate change and water consequences of producing more wool in response to an increase in demand were lower than impacts for current production. This is because coproduction of red meat from the wool production system would avoid the need to produce red meat in other systems.

Footprints also do not consider the market effects of production changes. Research into climate change mitigation for Australian wheat ${ }^{17}$ production showed that intensification of wheat production with additional $\mathrm{N}$ fertiliser resulted in climate change mitigation at a global level despite the wheat produced via intensification having a greater carbon footprint than current practices. This was because it reduced demand for wheat from systems that were more GHG intensive. Market effects are also important when considering climate change mitigation strategies such as revegetation. When agricultural land is revegetated to sequester atmospheric $\mathrm{C}$, a reduction in agricultural land use occurs locally, and this results in an increase in demand for land in other countries ${ }^{18}$. Shifting the burdens of agricultural production elsewhere can reduce the climate change mitigation that occurs from revegetating areas because it drives deforestation to maintain agricultural production.

This study aimed to fill a gap in existing knowledge by assessing the water and climate change consequences of ceasing dairy production in New South Wales, Australia, and replacing the dairy and coproducts with soy-derived products (i.e. soymilk and tofu), vegetable oil and protein meal.

\section{Materials And Methods}

\subsection{System and spatial boundaries}

We assessed the cradle-to-gate water and climate change impacts of ceasing dairy production in NSW. Due to concerns about the environmental and animal welfare issues around beef production, we assumed dairy and its co-products were replaced with plant-based functional equivalents (Table 1). 
Consequences were assessed on a regional basis for three regions; the North Coast, South Coast and Inland (Figure 3). These regions were used because they represent distinct agro-climatic zones. The North Coast of NSW has a sub-tropical climate while the South Coast is temperate and the Inland region of NSW has a Mediterranean climate. In addition, the Inland region of NSW is covered by the one river catchment (i.e. the Murray Darling Basin (MDB)). Where necessary, the system boundaries were expanded to include global production (as described in section 4.2)

Table 1

Parameters, their variation from the baseline value and the change in climate change impacts.

\begin{tabular}{|llll|}
\hline & & \multicolumn{2}{l|}{ GHG emissions (Mt CO2-e) } \\
\hline Parameter & $\begin{array}{l}\text { Variation } \\
\mathbf{( \% )}\end{array}$ & $\begin{array}{l}\text { Parameter } \\
\text { increase }\end{array}$ & $\begin{array}{l}\text { Parameter } \\
\text { decrease }\end{array}$ \\
\hline Proportion of land arable & 50 & -0.763018813 & -0.552734866 \\
\hline Proportion of raw milk as cream & 25 & -0.600267841 & -0.715485837 \\
\hline Soybean yield & 25 & -0.785978998 & -0.52977468 \\
\hline C sequestration in vegetation & 50 & -0.683936136 & -0.631817543 \\
\hline Water availability & 50 & -0.668027684 & -0.647725995 \\
\hline $\begin{array}{l}\text { Water requirements for irrigated soy } \\
\text { production }\end{array}$ & 25 & -0.653542705 & -0.665100396 \\
\hline
\end{tabular}

\subsection{Production and resource use changes}

Dairy production occurs on both arable (i.e. cropland) and non-arable land. Cropland vacated by dairy production was first assumed to be used grow soybeans to replace dairy products with soymilk after which soybeans for tofu production were grown. Growing soybean crops in succession is considered poor agronomics due to the build-up of disease and weeds that reduces crop yields so we assumed that a soybeans were grown in rotation with wheat. The timing of rotations differed between each region due to the North Coast having higher rainfall and the rotations are described in Table 2. Water used for dairy production was segregated into irrigation water and water used for livestock. This was done because in NSW extractions for irrigation are licenced differently to water extracted for livestock. Water used for irrigation on dairy farms was assumed to be redirected to the production of soymilk and then to irrigating soybean crops. Water used for livestock was assumed to be made available to other river users under relevant licencing provisions. Where soybean production in a region could not meet the mass required to replace all products and co-products, it was assumed that demand for global soybean production increased. Conversely, where soybean production exceeded demand for soymilk and tofu, the additional production was assumed to avoid global soybean production. The wheat produced in the soybean-wheat 
rotation was assumed to reduce demand for global wheat production. Dairy cattle are fed supplements that consist primarily of cereal and plant-based protein meal (e.g. canola meal) and it was assumed that the absence of feeding supplements avoided global production of wheat and protein meal. Cream is separated from the milk during processing. We assumed that cream was either used as unprocessed cream or processed to make butter. The reduction in cream production was assumed to increase demand for global vegetable oil, as a part replacement of fresh cream and to make margarine. The reduction in meat meal and offal was assumed to increase global demand for protein meal. A co-product of soymilk and tofu production is okara. Okara has limited uses ${ }^{19}$ so was assumed to be applied to wheat paddocks avoiding the need for $\mathrm{N}$ fertilisers on a 1:1 $\mathrm{N}$ mass basis.

Table 2

The function, functional equivalent and substitution basis for each product and co-product from NSW dairy production systems

\begin{tabular}{|llll|}
\hline Product/co-product & Function & Functional equivalent & Substitution basis \\
\hline Fresh milk & Human consumption & Soy milk & Volume \\
\hline Fresh cream & Human consumption & Soy milk/vegetable oil (2:1 ratio) & Volume \\
\hline Cream in butter & Human consumption & Vegetable oil & Volume \\
\hline Red meat & Human consumption & Tofu & Mass \\
\hline Hide & Leather & PVC & Mass \\
\hline Tallow & Multiple & Vegetable oil & Mass \\
\hline Offal & Pet meat & Protein meal & Protein mass \\
\hline Meat meal & Chicken/pork feed & Protein meal & Protein mass \\
\hline
\end{tabular}

Table 3

Descriptions of irrigated and dryland soy rotations for the North Coast, South Coast and Inland regions used in this study.

\begin{tabular}{|c|c|c|}
\hline Region & Irrigated soy rotation & Dryland soy rotation \\
\hline $\begin{array}{l}\text { North } \\
\text { Coast }\end{array}$ & $\begin{array}{l}\text { Irrigated soybeans and unirrigated } \\
\text { wheat annually. }\end{array}$ & $\begin{array}{l}\text { Unirrigated soybeans followed by unirrigated } \\
\text { wheat over a two-year period. }\end{array}$ \\
\hline $\begin{array}{l}\text { South } \\
\text { Coast }\end{array}$ & $\begin{array}{l}\text { Irrigated soybeans and unirrigated } \\
\text { wheat over a two year period. }\end{array}$ & $\begin{array}{l}\text { Unirrigated soybeans followed by unirrigated } \\
\text { wheat over a two year period. }\end{array}$ \\
\hline Inland & $\begin{array}{l}\text { Irrigated soybeans and unirrigated } \\
\text { wheat over a two year period. }\end{array}$ & $\begin{array}{l}\text { Unirrigated soybeans followed by unirrigated } \\
\text { wheat over a two year period. }\end{array}$ \\
\hline
\end{tabular}


Non-arable land is primarily used for growing out heifers to join the milking herd or to dry off cows that are due to calve. Under current market conditions this land would be used to graze beef cattle because the soils are too poor the land is too steep to crop. Our objective of replacing dairy and dairy co-products only with plant-based alternatives meant that the land could not be used to produce plant-based functional equivalents. We therefore assumed that non-arable land was allowed to revegetate and sequester atmospheric $\mathrm{C}$. $\mathrm{C}$ sequestration was estimated for a central point in each region using the Full Carbon Accounting model following the guidelines ${ }^{20}$ for the Human Induced Regeneration methodology developed by the Australian Government to issue carbon credits under the Emissions Reduction Fund ${ }^{21}$. C sequestration in regenerating areas is minimal during the initial years so the average $C$ sequestration over the first 10 years of the simulation was used for each region. Taking existing agricultural land was assumed to increase demand for marginal global agricultural land and this was accounted for using the iLUC framework of Schmidt and Weidema ${ }^{22}$.

Regional experts suggest that for many farms in the South Coast region, the most reasonable alternative land use if dairy production were to cease would be peri-urban development. Transforming agricultural land to peri-urban development would result in no meaningful agricultural production and would also increase water consumption because more properties would have access to stock and domestic water rights. This option was not included in the study due to a lack of available information on which to base assumptions.

\subsection{Sensitivity analysis}

Sensitivity analysis was used to test how sensitive the results of the study were to changes in key parameters (Table 1).

\subsection{Mitigation strategies}

We also tested what the consequences of ceasing NSW dairy production would be if two climate change mitigation strategies, feeding enteric methane inhibitors and capturing methane from manure collected at the dairy, were implemented across the NSW dairy industry as an theoretical alternative baseline. Roque, Salwen ${ }^{23}$ showed that dairy cows fed $1 \%$ Asparagopsis armata reduced enteric methane production, dry matter intake and milk production per cow by $67 \%, 38 \%$ and $11 \%$, respectively. To test the impact of enteric methane reduction inhibitors on results we assumed that enteric methane emissions and milk production per cow declined by those amounts. The reduction in total dry matter intake per cow would mean that more cows could be milked using the existing resources, so we assumed that the number of cows in the milking herd increased by $50 \%$. This $50 \%$ increase is lower than achievable based on changes to dry matter intake alone but increasing the numbers of milking cows will be limited to some extent by infrastructure (e.g., shade, laneways) and limiting the increase to $50 \%$ accounts for these limitations. For the methane capture mitigation strategy, it was assumed that effluent ponds were covered, and methane was flared converting it to $\mathrm{CO}_{2}$. 


\subsection{Life cycle inventory}

Inventory for dairy, soybean and wheat production were developed by modifying relevant inventory from AusLCl ${ }^{24}$ with values that represented each region and included all farm operations and inputs. Global production of soybean, vegetable oil and protein meal were represented by the appropriate inventory in the ecoinvent v3.5 consequential database ${ }^{25}$. Inventory used in the study can be obtained in SimaPro format by contacting the corresponding author of this publication.

\subsection{Input data}

A list of input data and their source used to develop inventory is available in Table 4. Regional experts were used to source or validate input data and consisted of dairy advisors and processors in each relevant region. 
Table 4

Input data for the South Coast, North Coast and Inland regions, and the source of the data, used in the study.

\begin{tabular}{|c|c|c|c|c|}
\hline & Region & & & \\
\hline Parameter & $\begin{array}{l}\text { South } \\
\text { Coast }\end{array}$ & $\begin{array}{l}\text { North } \\
\text { Coast }\end{array}$ & Inland & Source \\
\hline Milk production (L) & 540720000 & 275533000 & 258630000 & $\begin{array}{l}\text { Dairy Australia } \\
46\end{array}$ \\
\hline Milk/cow/day $(L)$ & 18.6 & 17.6 & 20.9 & $\begin{array}{l}\text { Dairy Australia } \\
47\end{array}$ \\
\hline Area/farm (ha) & 355 & 321 & 418 & $\begin{array}{l}\text { Dairy Australia } \\
47\end{array}$ \\
\hline Cows/farm (no) & 418 & 314 & 426 & $\begin{array}{l}\text { Dairy Australia } \\
47\end{array}$ \\
\hline Proportion of farm arable (\%) & 80 & 70 & 70 & Expert opinion \\
\hline Cull age of dairy cows (years) & 7 & 7 & 7 & Expert opinion \\
\hline Cow liveweight at culling (kg) & 566 & 544 & 553 & $\begin{array}{l}\text { Dairy Australia } \\
47\end{array}$ \\
\hline Calf liveweight at sale $(\mathrm{kg})$ & 100 & 100 & 100 & Expert opinion \\
\hline Irrigated soy yield (kg/ha) & 3000 & 4000 & 3000 & Expert opinion \\
\hline Dryland soy yield (kg/ha) & 2000 & 2500 & 1500 & Expert opinion \\
\hline Dryland wheat yield (kg/ha) & 3000 & 3000 & 2500 & Expert opinion \\
\hline Cream in raw milk (\%) & 5 & 5 & 5 & $\begin{array}{l}\text { Dairy Australia } \\
48\end{array}$ \\
\hline Proportion of cream sold fresh (\%) & 50 & 50 & 50 & Expert opinion \\
\hline $\begin{array}{l}\text { Daily dry matter intake as } \\
\text { supplement (\%) }\end{array}$ & 40 & 40 & 40 & $\begin{array}{l}\text { Dairy Australia } \\
47\end{array}$ \\
\hline Wheat in supplement (\%) & 80 & 80 & 80 & Expert opinion \\
\hline Canola meal in supplement (\%) & 20 & 20 & 20 & Expert opinion \\
\hline $\begin{array}{l}\text { Average annual lime application } \\
(\mathrm{kg} / \mathrm{ha})\end{array}$ & 500 & 500 & 500 & Expert opinion \\
\hline N applied to irrigated land (kg N/ha & 201 & 213 & 157 & $\begin{array}{l}\text { Dairy Australia } \\
47\end{array}$ \\
\hline
\end{tabular}




\begin{tabular}{|c|c|c|c|c|}
\hline & Region & & & \\
\hline $\begin{array}{l}\text { Napplied to non-irrigated pastures } \\
(\mathrm{kg} \mathrm{N} / \mathrm{ha})\end{array}$ & 113 & 133 & 12 & $\begin{array}{l}\text { Dairy Australia } \\
47\end{array}$ \\
\hline $\begin{array}{l}\text { Irrigation water available } \\
(\mathrm{ML} / \text { /region }))\end{array}$ & 12660 & 14641 & 5417 & $\begin{array}{l}\text { Dairy Australia } \\
47\end{array}$ \\
\hline Irrigation to grow one ha of soy $(M L)$ & 6 & 4 & 6 & Expert opinion \\
\hline Water for livestock (L/head/day) ${ }^{+}$ & 160 & 160 & 160 & $\begin{array}{l}\text { Dairy Australia } \\
49\end{array}$ \\
\hline C in vegetation ( $t / h a)$ & 0.42 & 0.44 & 0.28 & $\begin{array}{l}\text { Australian } \\
\text { Government } 50\end{array}$ \\
\hline Kangaroo methane (L/head/day) & 3.05 & 3.05 & 3.05 & Vendl, Clauss 51 \\
\hline Kangaroo density (head/ha) & 2 & 2 & 0.5 & Expert opinion \\
\hline Dressing percentage (\%) & 50 & 50 & 50 & Expert opinion \\
\hline Butcher waste (\%) & 32 & 32 & 32 & Expert opinion \\
\hline Proportion offal (\%) & 10 & 10 & 10 & Expert opinion \\
\hline Area of hide $\left(m^{2}\right)$ & 4.5 & 4.5 & 4.5 & Expert opinion \\
\hline Proportion tallow (\%) & 18 & 18 & 18 & Expert opinion \\
\hline Proportion meat meal (\%) & 30 & 30 & 30 & Expert opinion \\
\hline Oil in soy (\%) & 20 & 20 & 20 & Wikipedia \\
\hline soybeans in soymilk (kg/l) & 0.1 & 0.1 & 0.1 & $\begin{array}{l}\text { Grant and Hicks } \\
52\end{array}$ \\
\hline soybeans in tofu ( $\mathrm{kg} / \mathrm{kg})$ & 0.4 & 0.4 & 0.4 & $\begin{array}{l}\text { Mejia, Harwatt } \\
53\end{array}$ \\
\hline protein content of tofu (\%) & 12 & 12 & 12 & $\begin{array}{l}\text { Supermarket } \\
\text { tofu packaging }\end{array}$ \\
\hline protein content of red meat (\%) & 23 & 23 & 23 & Wikipedia \\
\hline protein content of meat meal (\%) & 50 & 50 & 50 & Expert opinion \\
\hline protein content of soy meal (\%) & 45 & 45 & 45 & Expert opinion \\
\hline
\end{tabular}

2.7 GHG emissions calculations 
GHG emissions associated with fertiliser use on farm, crop residue breakdown and dissolution of lime were calculated using the relevant methods from the Australian National Inventory report ${ }^{26}$. Where GHG emissions were dependent on other biophysical processes (e.g., leaching of nitrates), calculations from the Australian National Inventory report were also used. Although it is highly likely that soil organic carbon (SOC) would lost when converting grassland to cropland, the impacts of crop management practices on SOC are highly uncertain ${ }^{27}$ so we assumed that there was no change in SOC. Emissions calculations in background inventory that represented global demand of crops were not modified.

\subsection{Impact assessment}

Impact assessment was done using SimaPro v8.3.0 ${ }^{28}$ with the AusLCl indicator set ${ }^{29}$. AR6 GWP 100 of $273,29.8$ and 27.2 for $\mathrm{N}_{2} \mathrm{O}, \mathrm{CH}_{4}$ (fossil origin) and $\mathrm{CH}_{4}$ (non-fossil origin), respectively, were used in the study. Blue water stress impacts were assessed using the AWARE methodology ${ }^{5}$ and, because the North Coast and South Coast regions include multiple catchments, characterization factors for these regions were the average of all catchments in each region. This gave an AWARE characterization factor of 1.5, 1.2 and 92 for the North Coast, South Coast and Inland regions, respectively.

\section{Results}

\subsection{Changes in commodity production}

Ceasing dairy production in NSW reduced raw milk at the farm gate by 1,074 kt with the greatest reduction occurring in the South Coast region (Figure 1 ). Ceasing dairy production also resulted in a decrease in of the co-products red meat (4 kt), tallow (2 kt), meat meal (8 kt), offal (1 kt) and hides for leather (1 kt). Growing soybeans on arable land, both dryland and irrigated, produced $114 \mathrm{kt}$ of soybeans and the production of an additional $11 \mathrm{kt}$ of soybeans was displaced to global production to ensure dairy and dairy co-products were replaced. Production of soybeans in the South Coast and Inland regions was not adequate to replace dairy and dairy co-products whereas in the North Coast region, more soybeans were produced than required. An additional $156 \mathrm{kt}$ of wheat were produced in rotation with soybeans and this production combined with the wheat no longer fed to cattle as supplements resulted in $159 \mathrm{kt}$ of global wheat production being avoided. Global demand for protein meal increased $38 \mathrm{kt}$ to replace the meat meal and offal that comes from slaughtered dairy animals and replacing fat in cream and tallow increased demand for global vegetable oil by $8 \mathrm{kt}$.

\subsection{Land use}

An additional 66 kha of agricultural land was required to replace NSW dairy products and co-products. Ceasing dairy production in NSW freed up 142 kha of agricultural land but once changes were implemented, 105 kha of land freed up was used for soybean production and 37 kha used for revegetation to sequester atmospheric $\mathrm{C}$. At a global level, the wheat grown in rotation with soybeans resulted in 48 kha of land being freed up due to avoided global wheat production. The primary driver of 
overall increase in demand for agricultural land was indirect landuse change (iLUC) associated with using $37 \mathrm{kha}$ of non-arable land for sequestering $C$ in vegetation. iLUC impacts were greater in the North and South Coast regions than the Inland region (Figure 2) due to the greater net primary productivity of these regions. Additional land required to the production of global soy, protein meal and vegetable oil were relatively modest.

\subsection{Water consumption}

The blue water footprints of raw milk were 54, 24 and $21 \mathrm{~L} \mathrm{H}_{2} \mathrm{O} \mathrm{L}^{-1}$ for the North Coast, South Coast and Inland regions, respectively and the production weighted average for NSW was $39 \mathrm{~L} \mathrm{H}_{2} \mathrm{OL}^{-1}$. Ceasing dairy production resulted in $59 \mathrm{GL}$ of irrigation water and $8 \mathrm{GL}$ of livestock drinking water not being extracted from the river for dairy production, with the greatest savings occurring in the South Coast region (Figure 3). However, of that $59 \mathrm{GL}$ of irrigation water, $1 \mathrm{GL}$ was repurposed to produce soymilk and the remainder of irrigation water was used to grow soybeans. For global production, $2 \mathrm{GL}$ of water was required to grow global soybeans and vegetable oil and $4 \mathrm{GL}$ was required to produce protein meal whereas avoiding global wheat production reduced the consumption of water by $50 \mathrm{GL}$. The net balance at a global level was a reduction in water consumption by $52 \mathrm{GL}$, of which $8 \mathrm{GL}$ was water not consumed by livestock.

\subsection{Water stress impacts}

Water stress footprints for raw milk production were 81, 29 and $2011 \mathrm{~L} \mathrm{H}_{2} \mathrm{O}-\mathrm{e} \mathrm{L}^{-1}$ for the North Coast, South Coast and Inland regions, respectively with the average for NSW of $510 \mathrm{~L} \mathrm{H}_{2} \mathrm{O}-\mathrm{e} \mathrm{L}^{-1}$. Ceasing NSW dairy production reduced water stress impacts at a global level by $1,962 \mathrm{GL} \mathrm{H}_{2} \mathrm{O}$-e with the greatest reduction occurring in the North Coast region (Figure 4). Whilst ceasing NSW dairy production reduced water stress by $62 \mathrm{GL} \mathrm{H}_{2} \mathrm{O}$-e due to water no longer consumed by livestock, the greatest reduction occurred by water no longer used when global production of wheat was avoided.

\subsection{Climate change impacts}

The $\mathrm{C}$ footprints of raw milk production in the North Coast, South Coast and Inland regions were 1.24, 0.98 and $1.07 \mathrm{~kg} \mathrm{CO}^{-e} \mathrm{~L}^{-1}$, respectively with a production weighted C footprint for NSW of $1.07 \mathrm{~kg}$ CO2-e $\mathrm{L}^{-1}$. Results suggest that replacing dairy and dairy co-products with plant-based alternatives would reduce climate change impacts by $0.75 \mathrm{Mt} \mathrm{CO2-e.} \mathrm{The} \mathrm{greatest} \mathrm{reduction} \mathrm{occurred} \mathrm{in} \mathrm{the} \mathrm{South} \mathrm{Coast}$ region due to the volume of milk produced in that region (Figure 5). The GHG emissions associated with global vegetable oil production to replace tallow and cream, and emissions associated with iLUC were the main positive emissions associated with replacing dairy and dairy co-products with plant-based alternatives.

\subsection{Sensitivity analysis}


Results from sensitivity analysis (Table 1) suggests that the results of the analysis were relatively sensitive to proportion of each farm that was arable land, with an increase in the proportion of land that was arable reducing climate change impacts. Climate change impacts were also reduced when soybean yields increased. These results occurred because increasing arable land or soybean yield resulted in greater soybean production that reduced the need for global soybean production to replace dairy and dairy co-products. Results were also relatively sensitive to the proportion of cream in raw milk with an increase in the proportion of cream resulting in greater climate change impacts that were attributed to an increase in the production of global vegetable oil to replace cream.

\subsection{Climate change mitigation strategies}

The reduction in dry matter required to produce a litre of milk that occurred with the feeding of enteric methane inhibitors to dairy cattle resulted in the production of an additional $483 \mathrm{kt}$ of milk using the same amount of land and inputs. This increase in production combined with a $50 \%$ reduction in enteric methane emissions resulted in ceasing NSW dairy production increasing $\mathrm{GHG}$ emissions by $0.46 \mathrm{Mt} \mathrm{CO}_{2}^{-}$ e. Covering effluent ponds to capture methane and flaring it as $\mathrm{CO}_{2}$ further reduced emissions so that if both climate change mitigation strategies were implemented ceasing NSW dairy production would increase climate change impacts by $0.57 \mathrm{Mt} \mathrm{CO}_{2}$-e.

\section{Discussion}

The purpose of this research was not to obtain a definitive estimate of the water and climate change consequences of ceasing NSW dairy. Rather it was to examine the changes in requirements for land and water to replace dairy and dairy co-products from NSW dairy production with reasonable functional equivalents and the water stress and climate change impacts of doing so. The scenario assessed here (soy, vegetable oil) is one of many possible scenarios that could occur if NSW dairy production were to cease. Based on the water and carbon footprints developed by this study it would be estimated that ceasing NSW dairy production would reduce water use and GHG emissions by $67 \mathrm{GL}$ and $1.15 \mathrm{Mt} \mathrm{CO}_{2}$-e, respectively. Our analysis suggests that this would not be the case and that water savings and GHG emissions reductions of $52 \mathrm{GL}$ and $0.75 \mathrm{Mt} \mathrm{CO}_{2}-\mathrm{e}$, respectively, would occur meaning that the benefits achieved by ceasing NSW dairy production would be 77 and $65 \%$ less than expected reductions in environmental impacts based on footprints.

A saving of $52 \mathrm{GL}$ of blue water occurred at a global scale was largely attributed to global wheat production, that includes a large proportion of irrigated production, being displaced to dryland wheat production in NSW. If we focus only on the water savings that would occur for the state of NSW, then no water saving may potentially occur. Numerous studies have highlighted the rebound effect applies to water savings associated with efficiency measures (i.e. water that becomes available due to efficiency measures is consumed by other uses $)^{30,31,32,33}$ and we have assumed that a rebound effect occurs here for irrigation water, when water is made available for irrigation by dairy production ceasing. This is justified because water is a tradeable asset, and the purpose of the water markets is to ensure that the 
water extractions allowed by legislation for irrigation purposes are directed to the highest value use. This meant that water savings only came from unused stock water. The extraction of water for stock and domestic uses is a basic right of any landholders whose land adjoins a waterway under NSW water legislation ${ }^{34}$. We posit that the rebound effect would also apply to the stock and domestic water freed up by ceasing dairy production, especially during periods of low flow when demand is at its greatest. Including this rebound effect in the study was not possible due to difficulties in quantification of the impacts. We propose, however, that water savings in each region are likely to have been overestimated in our study because at least some, if not all, unused stock and domestic water would be extracted by other river users because more water is available for extraction. What is clear, is a cessation of dairy production in NSW by either a policy initiative or by altering consumer demand on the basis of the water footprint of current production will not result in the expected water savings. Furthermore, using a water footprint does not consider other water related impacts associated with changes to production. For example, converting pastures to cropland for soybean production would reduce water quality because sediment runoff is greater on cropland ${ }^{35}$ and revegetating areas could increase rainfall interception and reduce inflows ${ }^{36}$. Impacts such as these were not included due to difficulties in quantifying impacts and should be the focus of future work that aim to better understand the environmental consequences of industry wide changes to production.

The NSW dairy industry recognises that efforts to reduce the GHG emissions associated with dairy production are needed ${ }^{24}$ with some agricultural sectors (e.g. red meat production) adopting Carbon Neutral targets ${ }^{37}$. The present study has demonstrated that if climate change mitigation strategies were put in place then replacing an industry with relatively high climate change impacts would exacerbate climate change. We argue that in order for an industry to become carbon neutral not all GHG emission need to be offset, rather enough GMG emissions need to be offset so that if demand shifted to alternatives then there would be a high degree of confidence that climate change impacts would increase. This means that under the assumptions used in our study, reducing the GHG emissions of the NSW dairy industry by $0.75 \mathrm{Mt} \mathrm{CO}_{2}$-e, as opposed to $1.15 \mathrm{Mt} \mathrm{CO}_{2}$-e based on the footprint of production, would be adequate to offset any climate change benefits that would occur if dairy production ceased completely and, thus, make the NSW dairy industry carbon neutral.

Our analysis suggests that an emissions reduction greater than the required $0.75 \mathrm{Mt} \mathrm{CO}_{2}$-e could be achieved by feeding milking cows enteric methane inhibitors in their daily ration. The existence of numerous Asparagopsis production enterprises, such as FutureFeed, indicate that implementing this strategy is realistic and achievable in the short-term. Stacking enteric methane reductions with methane capture of effluent ponds further reduced emission and the existence of other climate change mitigation strategies not included in the present study, such as co-producing heat and electricity from captured methane and/or solar-generated electricity and battery storage to avoid fossil fuel derived electricity, the use of nitrification inhibitors to reduce fertiliser $\mathrm{N}_{2} \mathrm{O}$ emissions ${ }^{26}$ and electric tractors powered by renewable electricity to reduce fossil fuel emissions means we are confident that the NSW dairy industry can continue into the future with less impacts than obtaining plant-based alternatives to dairy and dairy 
co-products. These results should provide impetus for the NSW dairy industry to implement GHG emissions reductions strategies and improve its social licence to operate.

Availability of land to produce replacements for dairy production was a key factor influencing the results of the analysis. The production of functional equivalents of NSW dairy products and co-products required an additional 66,000 ha of global agricultural land than required for dairy production. It is common for global production to play a critical role in food security with research suggesting that less than one-third of the global population can exist on locally supplied food ${ }^{38}$ so where additional demand of crop land is required to meet demands it is imperative that the climate change impacts of LUC are considered ${ }^{39}$. In our study, this additional land was required for global soybean production, vegetable oil and protein meal and also to compensate for the loss of non-arable land on which trees were planted to sequester atmospheric $\mathrm{C}$. The GHG emissions associated with these changes are included in our results either embedded in the climate change impacts of global commodities or as iLUC impacts (Figure 5). Avoiding global displacement and the climate change impacts of LUC could not have been avoided by assuming that soybeans, vegetable oil and meal were grown on existing crop land in other parts of Australia. Rather, utilising existing cropland in Australia would result in the displacement of crops that soybean, vegetable oil and protein meal replace to global production ${ }^{15,17}$ resulting in LUC.

Results were clearly sensitive to parameters that had an impact on soybean production (Table 1) however we are confident in the robustness of estimates of yields and proportion of land arable per farm. Further, the results were not sensitive enough to change the conclusion that, as things currently stand, replacing dairy and dairy co-products with plant-based alternatives would provide climate change mitigation. It would be useful to re-do this analysis to reflect improvements in production technologies and the implementation of climate change mitigation strategies over time and integrate improvements in information relating to LUC in response to demand for agricultural land. Any future analysis would also benefit from using disaggregated data to better reflect regional variability in resource availability/use and management. The process used here to assess consequences can also be used at larger spatial scales where displacement of cropland can be better informed to develop optimal outcomes.

Footprints remain the metric of choice to inform decisions ${ }^{40,41}$ despite a growing body of evidence that the consequences of change in demand are not supported by footprints $14,15,16,17,42,43,44,45$. The present study supports this by showing the consequences of changes are not aligned with footprints of current production. This work also shows that, despite still not being carbon neutral, implementing key climate change mitigation strategies would mean that ceasing NSW dairy production and replacing it with plantbased alternatives would increase climate change impacts. Hence, carbon neutral targets need to be based on potential consequences of change not on footprints.

\section{Declarations}

Acknowledgements 
This research was supported by funding from the Australian Government Department of Agriculture, Water and the Environment as part of its Rural R\&D for Profit program. The authors would like to thank the farmers and advisors that provided data input for the project.

\section{Competing interests}

The authors declare the existence of a financial/non-financial competing interest.

\section{References}

1. Zhang $X$, et al. Milk consumption and multiple health outcomes: umbrella review of systematic reviews and meta-analyses in humans. Nutrition \& Metabolism 18, 7 (2021).

2. Ridoutt BG, Baird D, Hendrie GA. The role of dairy foods in lower greenhouse gas emission and higher diet quality dietary patterns. Eur J Nutr 60, 275-285 (2021).

3. ABS. 7503 - Value of Agricultural Commodities Produced.) (2020).

4. ABS. 4610 - Water Account.) (2020).

5. Boulay A-M, et al. The WULCA consensus characterization model for water scarcity footprints: assessing impacts of water consumption based on available water remaining (AWARE). Int J Life Cycle Assess 23, 368-378 (2018).

6. Ridoutt B, Williams S, Baud S, Fraval S, Marks N. The water footprint of dairy products: Case study involving skim milk powder. J Dairy Sci 93, 5114-5117 (2010).

7. Kovacs B, Miller L, Heller MC, Rose D. The carbon footprint of dietary guidelines around the world: a seven country modeling study. Nutrition Journal 20, 15 (2021).

8. Marinova D, Bogueva D. Which 'milk'is best for the environment? We compared dairy, nut, soy, hemp and grain milks. (2020).

9. Berners-Lee M. How bad are bananas?: the carbon footprint of everything. Profile Books (2020).

10. Poore J, Nemecek T. Reducing food's environmental impacts through producers and consumers. Science 360, 987-992 (2018).

11. Simmons AT, Perovic DJ, Roth G. Are waterfootprints suitable to inform consumers: an example of the Murray Darling Basin. Australian Farm Policy Journal, (in press).

12. Perry C. Water footprints: path to enlightenment, or false trail? Agric Water Manag 134, 119-125 (2014).

13. Plevin RJ, Delucchi MA, Creutzig F. Using Attributional Life Cycle Assessment to Estimate Climate Change Mitigation Benefits Misleads Policy Makers. J Ind Ecol 18, (2013).

14. White RR, Hall MB. Nutritional and greenhouse gas impacts of removing animals from US agriculture. Proceedings of the National Academy of Sciences 114, E10301 (2017).

15. Smith LG, Kirk GJD, Jones PJ, Williams AG. The greenhouse gas impacts of converting food production in England and Wales to organic methods. Nature Communications 10, 4641 (2019). 
16. Wiedemann SG, Simmons A, Watson KJL, Biggs L. Effect of methodological choice on the estimated impacts of wool production and the significance for LCA-based rating systems. Int J Life Cycle Assess 24, 848-855 (2019).

17. Simmons AT, Cowie A, Brock PM. Climate change mitigation for Australian wheat production. Sci Total Environ, 138260 (2020).

18. Meyfroidt $P$, Rudel TK, Lambin EF. Forest transitions, trade, and the global displacement of land use. Proceedings of the National Academy of Sciences 107, 20917-20922 (2010).

19. Li B, Qiao M, Lu F. Composition, Nutrition, and Utilization of Okara (Soybean Residue). Food Rev Int 28, 231-252 (2012).

20. Australian Government. Requirements for using the Full Carbon Accounting Model (FullCAM) in the Emissions Reduction Fund (ERF) methodology determination: Carbon Credits (Carbon Farming Initiative - Human induced Regeneration of a Permanent Even Aged Native Forest - 1.1) Methodology Determination GVariation 2013. (ed Government A) (2020).

21. Australian Government. Carbon Credits (Carbon Farming Initiative - Human induced Regeneration of a Permanent Even Aged Native Forest - 1.1) Methodology Determination GVariation 2016. In: F2016L00361 (ed Government A) (2016).

22. Schmidt JH, Weidema BP, Brandão M. A Framework for Modelling Indirect Land Use Changes in Life Cycle Assessment. Journal of Cleaner Production, (2015).

23. Roque BM, Salwen JK, Kinley R, Kebreab E. Inclusion of Asparagopsis armata in lactating dairy cows' diet reduces enteric methane emission by over 50 percent. Journal of Cleaner Production 234, 132138 (2019).

24. Grant T, Eady S, Cruypenninck H, Simmons A. AusLCl methodology for developing Life Cycle Inventory for Australian agriculture.). Lifecycle Strategies Pty Ltd (2017).

25. Weidema B, et al. The ecoinvent database: Overview and methodology, Data quality guideline for the ecoinvent database version 3.). St Gallen, Switzerland, http://www. ecoinvent. org (accessed 21/09/2015). Maskell, Heath and Walker (2013).

26. Australian Government. Australian National Greenhouse Accounts National Inventory Report 2016.). Department of the Environment and Energy (2018).

27. Badgery WB, et al. Relationship between environmental and land-use variables on soil carbon levels at the regional scale in central New South Wales, Australia. Soil Res 51, 645-656 (2014).

28. PRé Sustainability. Simapro v8.3.0.). 8.3.0 edn (2016).

29. Renouf MA, et al. Best Practice Guide for Life Cycle Impact Assessment (LCIA) in Australia.). Australian Life Cycle Assessment Society (2015).

30. Berbel J, Gutiérrez-Martín C, Rodríguez-Díaz JA, Camacho E, Montesinos P. Literature review on rebound effect of water saving measures and analysis of a Spanish case study. Water Resources Management 29, 663-678 (2015). 
31. Wheeler SA, Carmody E, Grafton RQ, Kingsford R, Zuo A. The rebound effect on water extraction from subsidising irrigation infrastructure in Australia. Resources, Conservation and Recycling 159, 104755 (2020).

32. Song J, Guo Y, Wu P, Sun S. The agricultural water rebound effect in China. Ecol Econ 146, 497-506 (2018).

33. Loch A, Adamson D. Drought and the rebound effect: a Murray-Darling Basin example. Natural Hazards 79, 1429-1449 (2015).

34. Government N. Water Management Act 2000 no 92. (ed Governmnet N) (2000).

35. Zhang X, Lark TJ, Clark CM, Yuan Y, LeDuc SD. Grassland-to-cropland conversion increased soil, nutrient, and carbon losses in the US Midwest between 2008 and 2016. Environmental Research Letters 16, 054018 (2021).

36. Khorchani M, Nadal-Romero E, Lasanta T, Tague C. Natural revegetation and afforestation in abandoned cropland areas: Hydrological trends and changes in Mediterranean mountains. Hydrological Processes 35, e14191 (2021).

37. Mayberry D, Bartlett H, Moss J, Davison T, Herrero M. Pathways to carbon-neutrality for the Australian red meat sector. Agric Sys 175, 13-21 (2019).

38. Kinnunen $\mathrm{P}$, et al. Local food crop production can fulfil demand for less than one-third of the population. Nature Food 1, 229-237 (2020).

39. Brandão M, Azzi E, Novaes RML, Cowie A. The modelling approach determines the carbon footprint of biofuels: The role of LCA in informing decision makers in government and industry. Cleaner Environmental Systems 2, 100027 (2021).

40. Sustainable Apparel Coalition. Higg Materials Sustainability Index (MSI) Methodology.). Sustainable Apparel Coalition (2016).

41. Manfredi S, Allacker K, Pelletier N, Chomkhamsri K, de Souza DM. Product environmental footprint (PEF) guide. (2012).

42. Ngyuen Q, Wiedemann SG, Simmons AT. The environmental consequences of a change in Australian cotton lint production. Int $J$ Life Cycle Assess, (in review).

43. Abdul-Manan AFN. Lifecycle GHG emissions of palm biodiesel: Unintended market effects negate direct benefits of the Malaysian Economic Transformation Plan (ETP). Energy Policy 104, 56-65 (2017).

44. Khan MMH, Deviatkin I, Havukainen J, Horttanainen M. Environmental impacts of wooden, plastic, and wood-polymer composite pallet: a life cycle assessment approach. Int J Life Cycle Assess 26, 1607-1622 (2021).

45. Trostle R. Global agricultural supply and demand: factors contributing to the recent increase in food commodity prices (rev. DIANE Publishing (2010).

46. Dairy Australia. Milk Production Reports.) (2021).

47. Dairy Australia. NSW Dairy Farm Monitor report.) (2021). 
48. Dairy Australia. In focus 2020: The Australian dairy industry.) (2020).

49. Dairy Australia. Stock water budgeting tool.) (2021).

50. Australian Government. Full Carbon Accounting Model (FullCAM).). 4.1.6.19417 edn (2018).

51. Vendl C, et al. Decreasing methane yield with increasing food intake keeps daily methane emissions constant in two foregut fermenting marsupials, the western grey kangaroo and red kangaroo. The Journal of Experimental Biology 218, 3425-3434 (2015).

52. Grant CA, Hicks AL. Comparative life cycle assessment of milk and plant-based alternatives. Environ Eng Sci 35, 1235-1247 (2018).

53. Mejia A, Harwatt H, Jaceldo-Siegl K, Sranacharoenpong K, Soret S, Sabaté J. Greenhouse Gas Emissions Generated by Tofu Production: A Case Study. Journal of Hunger \& Environmental Nutrition 13, 131-142 (2018).

\section{Figures}

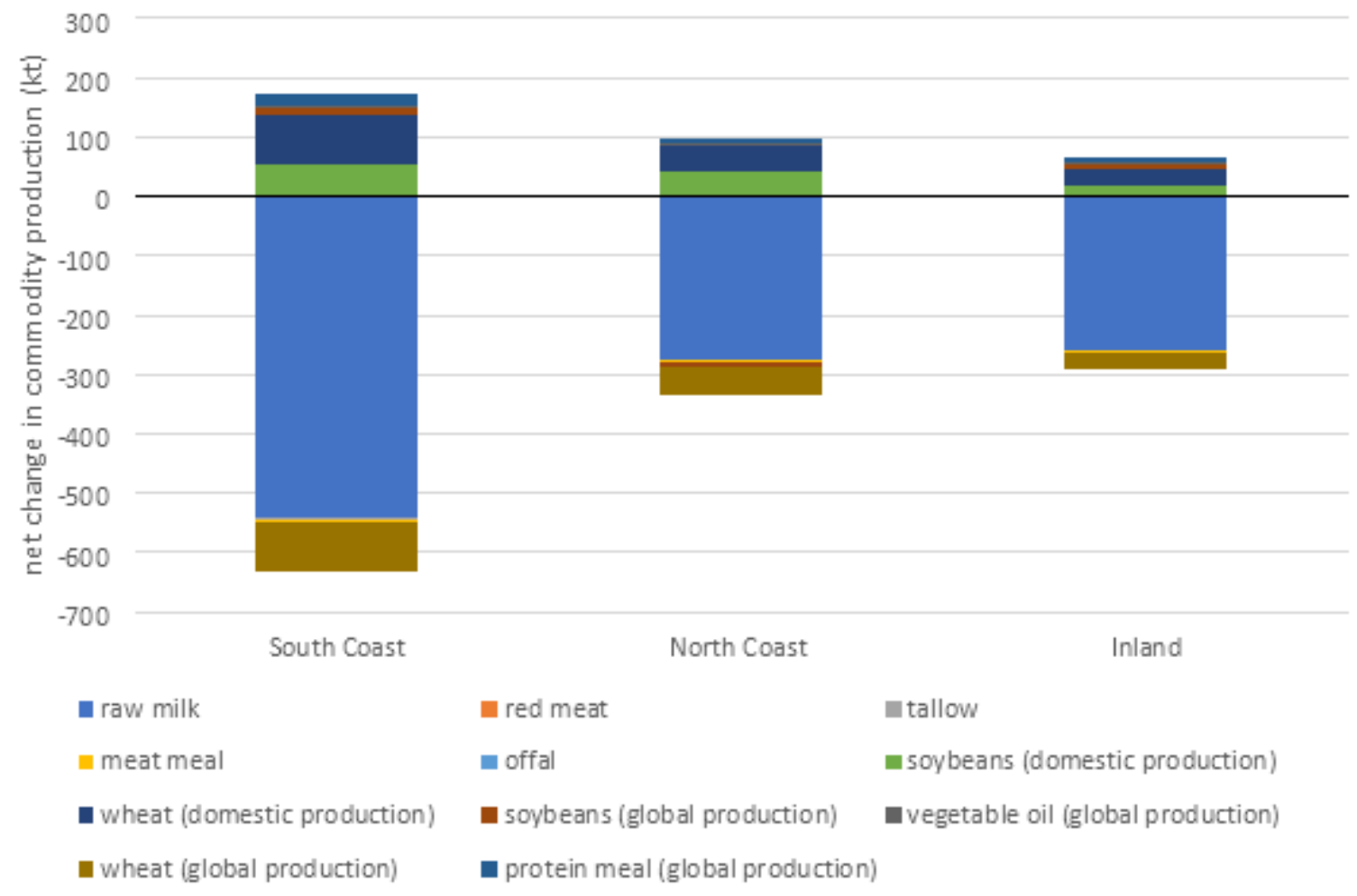

\section{Figure 1}

Changes to commodity production when dairy and dairy co-products for South Coast, North Coast and Inland regions are substituted with soy products and vegetable oil. 


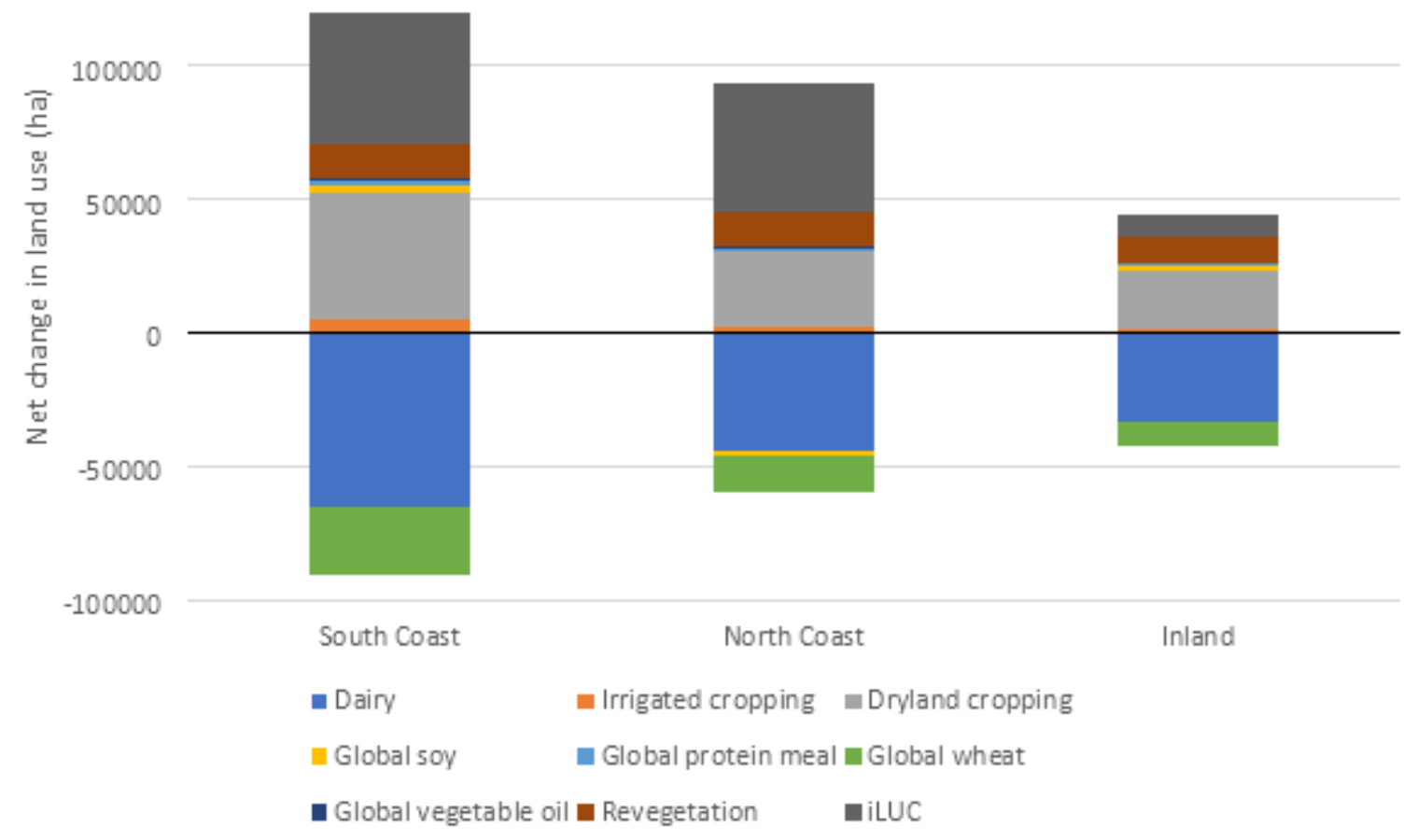

\section{Figure 2}

Changes in land use when dairy and dairy co-products for South Coast, North Coast and Inland regions are substituted with soy products and vegetable oil.

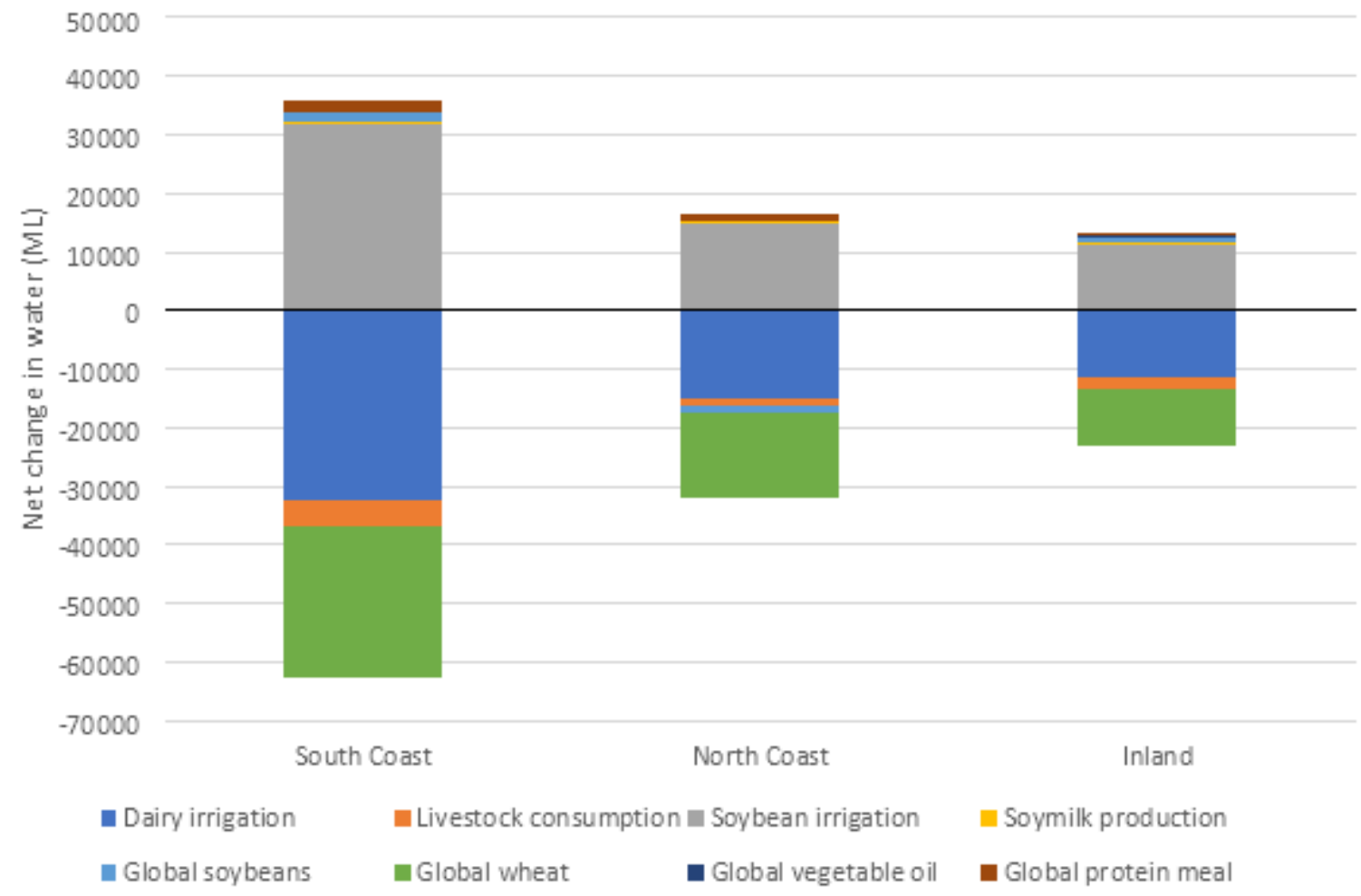

Figure 3 
Changes in water consumption when dairy and dairy co-products for South Coast, North Coast and Inland regions are substituted with soy products and vegetable oil.

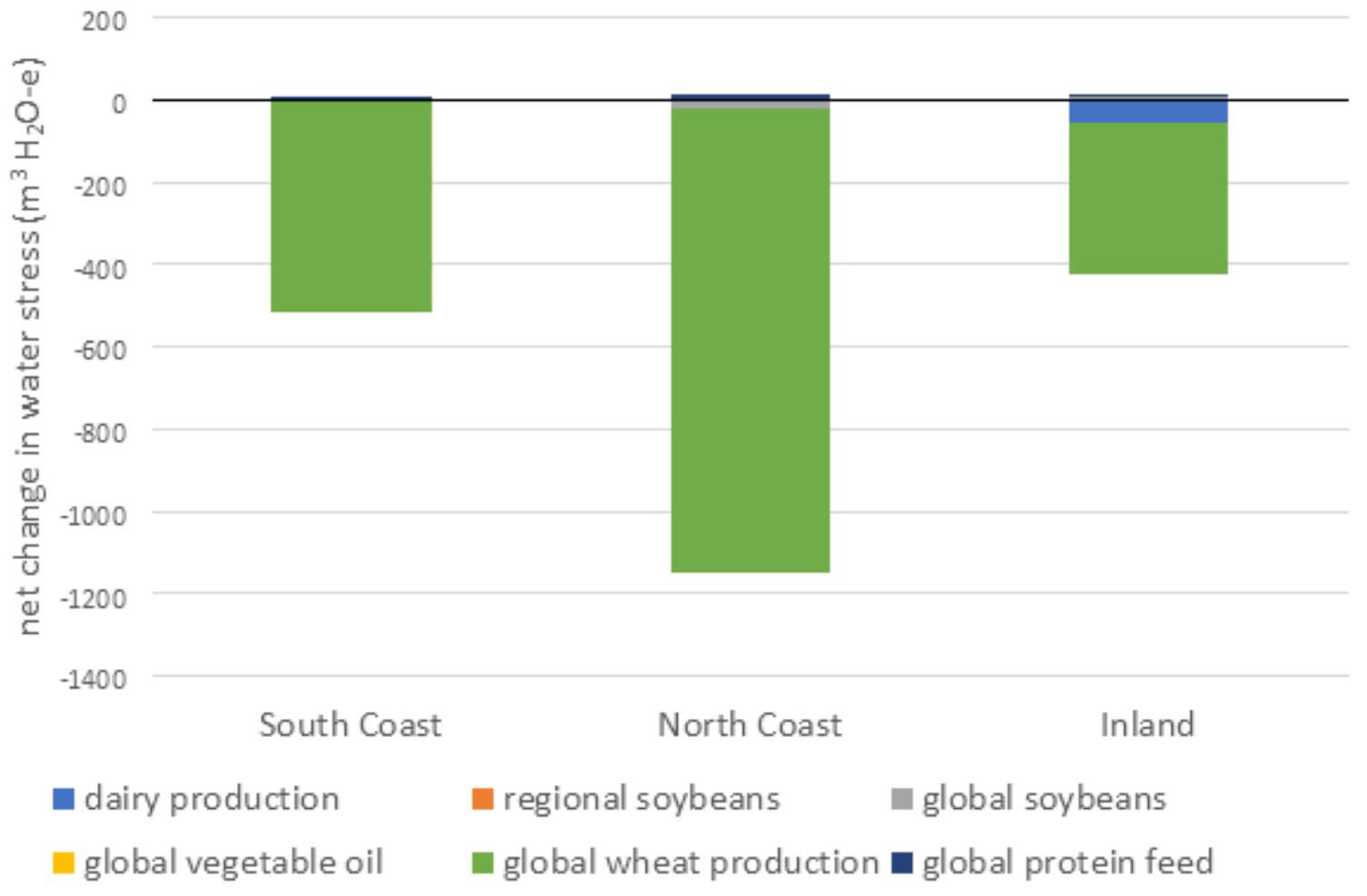

\section{Figure 4}

Changes in AWARE water stress impacts when dairy and dairy co-products for South Coast, North Coast and Inland regions are substituted with soy products and vegetable oil. 


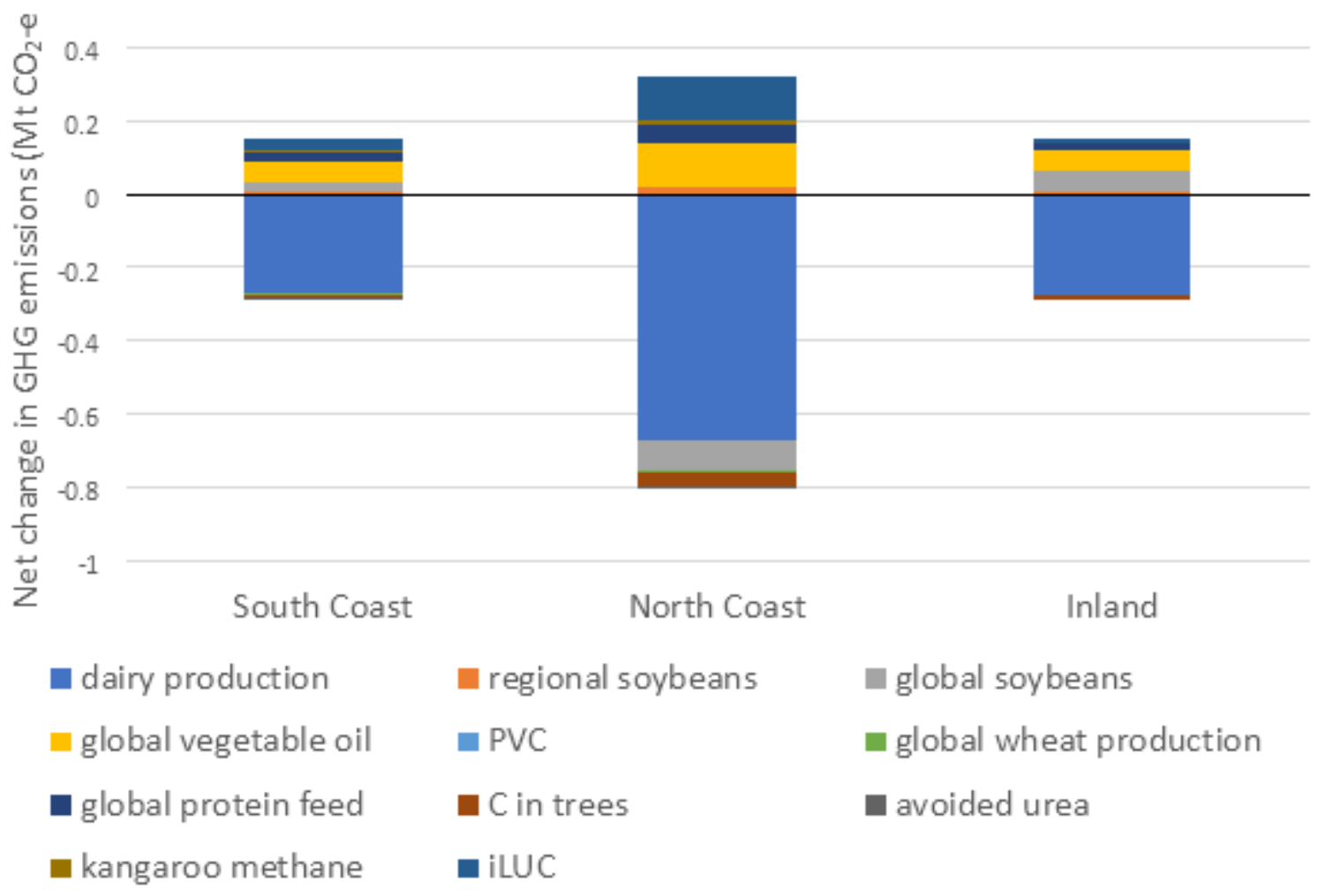

\section{Figure 5}

Changes in GHG emissions when dairy and dairy co-products for South Coast, North Coast and Inland regions are substituted with soy products and vegetable oil. 


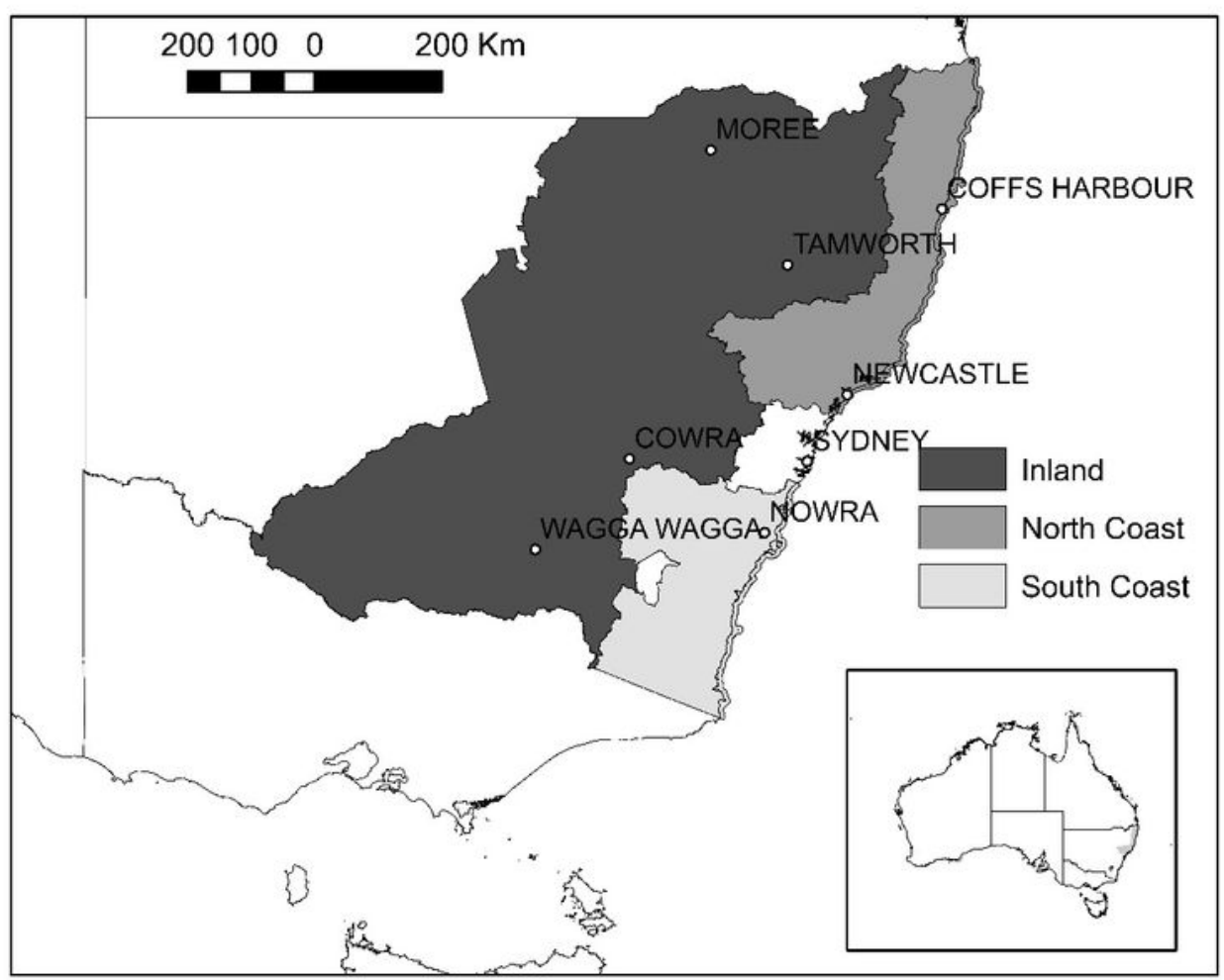

Figure 6

Map of NSW showing the boundaries of the North Coast, South Coast and Inland regions used in the study. 